\title{
A systematic review of financial toxicity among cancer survivors: we can't pay the co-pay
}

Louisa G Gordon ${ }^{1}$, Katharina M D Merollini ${ }^{2}$, Anthony Lowe ${ }^{3,4}$, Raymond J Chan ${ }^{5,6}$

\section{Affiliations:}

1. QIMR Berghofer Medical Research Institute, 300 Herston Rd, Herston Q4006, Brisbane, Australia

2. University of the Sunshine Coast, Faculty of Science, Health, Education and Engineering, Maroochydore DC Q4558, Sunshine Coast, Australia

3. Prostate Cancer Foundation of Australia, St Leonards, NSW 2065, Sydney Australia

4. Griffith University, Menzies Health Institute Queensland, Southport Q4215, Gold Coast Australia

5. Queensland University of Technology, School of Nursing, Victoria Park Rd, Kelvin Grove, Q4059, Brisbane Australia

6. Royal Brisbane and Women's Hospital, Cancer Care Services, Herston Q4029, Brisbane Australia

Correspondence to: Louisa Gordon, QIMR Berghofer Medical Research Institute, Population Health, 300 Herston Rd, Herston Q4006, Brisbane, AUSTRALIA Ph:61-7-3362 3717 Fx:61-7-3845 3502 louisa.gordon@qimrberghofer.edu.au

Running head: Review of financial toxicity among patients with cancer

\section{Acknowledgements}

Authors LG and KM planned the search strategy, and performed searches and extracted the data into tables and Endnote. Authors LG and KM drafted the paper with assistance from authors RC and AL. Authors RC and AL provided consumer and clinical insights to the project and the written draft. Authors LG synthesized the findings and produced summary information and results Figure 2. All authors contributed to writing and editing the final draft and have approved the submitted version.

\section{Compliance with Ethical Standards}

The authors received no funding assistance to conduct this study. Author KM, author AL and author RC have no conflicts of interest to disclose. Consultancy fees for related work were received in 2013 by Author LG. 


\section{Abstract $(\max 250)$}

Objective: To determine the extent of financial toxicity (FT) among cancer survivors, identify the determinants and how it is measured.

Methods: A systematic review was performed in MEDLINE, CINAHL and PsycINFO, using relevant terminology and included articles published from 1 January 2013 to 30 June 2016. We included observational studies where the primary outcomes included financial toxicity and study samples were greater than 200. The Preferred Reporting Items for Systematic Reviews and Meta-Analyses (PRISMA) guidelines were followed.

Results: From 417 citations, a total of 25 studies were included in this review. Seventy measures of FT were reported with 47 covering monetary indicators, objective and subjective indicators of FT. A total of $28-48 \%$ of patients reported FT using monetary measures and $16-73 \%$ using subjective measures. The most commonly reported factors associated with FT were: being female, younger age, low income at baseline, adjuvant therapies and more recent diagnosis. Relative to non-cancer comparison groups, cancer survivors experienced significantly higher FT. Most studies were crosssectional and causal inferences between FT and determinants were not possible. Measures of FT were varied and most were not validated while monetary values of out-of-pocket expenses included different cost components across studies.

Conclusions: A substantial proportion of cancer survivors experience financial hardship irrespective of how it is measured. Using standardized outcomes and longitudinal designs to measure FT would improve determination of the extent of FT. Further research combining reduction of work participation with resulting income losses occurring concurrently with FT and impacts on treatment non-adherence is recommended.

\section{Key Points for Decision Makers}

- Financial toxicity can affect a substantial number of patients with cancer, even those in universal health care systems or with health insurance.

- More recognition and research is needed on the dual problem of high out-of-pocket costs and reduced income as work participation declines following cancer.

- Patients and providers need to take control for seeking information on costs and exploring inexpensive options to minimize this problem. 


\subsection{INTRODUCTION}

'The greater threats to our national public health system lie in the increasing role of consumer copayments and the power of vested interests that stifle policy innovation in health' (Stephen Duckett in response to privatisation of Australian Medicare, Director, Health Program, Grattan Institute, June 23, 2016)

Patients with cancer can face serious financial challenges. In part, this is due to the high costs associated with advancements in technologies and treatments such as new pharmacotherapies, surgical techniques, imaging, and genetic testing [1]. Cancer survivors are also living longer with their cancer as a chronic illness and with the accompanying demands to monitor the disease and its sequelae [2]. As most health systems, including both public and private providers, face tight budgets, there is increasing reliance on patients to make larger co-payments and financial contributions to their healthcare. Even in countries where there is universal health care or when individuals have health insurance, additional patient out-of-pocket expenses are commonplace $[1,3]$.

The term 'financial toxicity' (FT) is defined in oncology research and practice to describe the financial distress or hardship that may be a side-effect of cancer treatment. [1, 4, 5]. Aptly coined for the financial pain of receiving cancer treatment, the term describes persons with high out-of-pocket (OOP) medical expenses and the impacts on poorer quality of life and reduced health care. In this sense, it is very similar to other treatment toxicities like neutropenia, nausea, vomiting, insomnia, or depression that lead to poorer patient outcomes and at times treatment delays/discontinuation. There are several options faced by patients when they are unable to afford medical care $[1,4,5]: 1$ ) they borrow money 2) they forgo other types of spending to pay for the health care; 3 ) they reduce their use of care (i.e., forgo or delay appointments, do not fill scripts, ration medications) or, in severe cases; 3 ) they forgo treatment entirely (including not presenting to a physician to diagnose cancer).

There is no gold standard definition of FT and the terms financial hardship, financial burden and FT are used interchangeably. However, the degree of financial burden has two contributors; high medical payments by individuals and reduced income while being treated or recovering from cancer. The combination of both a household's financial outgoings and incomings determine the extent of financial burden. The ways that individuals cope with financial burden fall into two broad categories: raising income (i.e., seeking financial assistance, early return to work, increasing debt/borrowings) or reducing spending (i.e., forgoing or delaying healthcare, choosing a less expensive option).

The experience of financial hardship varies for citizens in different regions around the world. In low income countries, patients with cancer may not even present to health services for care when symptoms arise or only present to a doctor when the cancer has spread and death is imminent [6]. Exacerbating this problem is the poor provision of a public health sector for citizens or other cultural or geographical barriers to receive cancer treatment [7]. In high income countries, patients with cancer often believe they are sufficiently protected from high medical costs through their health insurance policies only to discover inadequate coverage and subsequent 'bill shock' as invoices arrive [5]. Health systems classified as having 'universal health coverage' may not be comprehensive in practice, for example, Australia does not have universal dental services [3].

Although any disease may cause financial hardship among households, the term 'financial toxicity' originated in the context of cancer [5]. This is due to the very high cost of oncology medicines, the 
multiple and protracted treatment regimens, prolonged survival in cancer patients, and ageing populations with subsequent increased prevalence of common cancers [5]. The purpose of this review was to address the following research questions: What is the extent of FT among cancer survivors?, how is it measured?, and what are the factors associated with FT? We intentionally kept this review focused to studies published since January 2013 to provide the most up to date evidence on this topic. This enabled the review to be manageable, reflect current data collections and excluded exploratory studies. We also aimed to identify the latest measurement approaches on this topic, those that may have been derived from the exploratory studies.

\subsection{METHODS}

\subsection{Search strategy}

The review was performed following the Preferred Reporting Items for Systematic Reviews and Meta-Analyses (PRISMA) guidelines for systematic reviews [8]. We reviewed the recent medical literature on FT of cancer care using MEDLINE, PsycINFO and CINAHL. Reference lists of the included articles were screened to identify any other eligible studies. We included all types of cancer and all ages of cancer survivors. Studies that examined FT due to treatment (including cost, productivity loss, expense, treatment cost, out-of-pocket, economic burden, financial toxicity, financial hardship, financial burden, financial effect, financial stress, co-payment) in cancer patients were the primary focus. To increase homogeneity and comparability of included studies, papers assessing productivity losses or return to work issues but did not consider FT were excluded. We excluded studies that did not have solely cancer samples and the following study designs: qualitative studies, literature reviews, cost-effectiveness studies, commentaries and published abstracts. Qualitative studies were excluded because they tend to address why and how participants might be experiencing FT while cost-effectiveness studies primarily deal with evaluating cancer interventions and therefore FT is not their primary focus.

The following inclusion and exclusion criteria were applied:

Inclusion criteria:

- FT of cancer patients due to treatment is primary interest

- Published between January 2013- June 2016

- Any type of cancer

- Quantitative study

Exclusion criteria:

- $\quad$ FT was not the main focus of the article

- Published prior to 2013

- Funded by industry

- Wrong study design (as defined above)

- Small sample size: $\mathrm{n}<200$

\subsection{Search terms}

We grouped our review topic into four groups: cancer (1), patients (2), cost (3) and health outcomes (4). Synonyms and related terms were detailed (as below) For each of the terms in the four groups, 
we used Boolean operator 'OR' and between the groups we used 'AND'.. We used medical subject headings (MeSH) when available.

1) Cancer care, oncology, treatment, management, p(a)ediatric, breast, prostate, colorectal, cervical, thyroid, brain, lung, lymphoma, stomach, liver; MeSH cancer

2) Patient, survivor, sufferer, family; MeSH patient care

3) Cost, productivity loss, expense, treatment cost, out-of-pocket, economic burden, financial toxicity, financial hardship, financial burden, financial effect, financial stress, copayment; MeSH cost analysis

4) Outcome, life, well-being, effect, health, survival, stress, mental health, impact; MeSH quality of life, MeSH mortality, MeSH morbidity, MeSH burden of illness

Searches were restricted by date but not limited by language. To increase the accuracy of results and to minimise screening of irrelevant studies, only searches with $<50$ results were exported and duplicates removed. The search strategy was developed by one researcher and validated by a second researcher. Final searches were performed on 22/7/2016.

\subsection{Screening \& data extraction}

Initially, titles were screened for inclusion according to our pre-specified inclusion criteria. Subsequently abstracts of potentially eligible citations were screened. Reasons for exclusion were documented. This process was independently performed by two authors (KM \& LG) and discrepancies were discussed until an agreement was reached.

The assessment of the full text articles retrieved were assessed for inclusion by two reviewers who shared this task equally and together agreed on the final set of included studies. Key information of eligible articles was extracted into a table by two authors (KM \& LG) to summarise the features and main findings of the studies.

\subsection{Data synthesis \& quality}

Study quality was assessed using the National Institute of Health Quality Assessment Tool for Observational Cohort and Cross-Sectional Studies [9]. This tool asks 14 questions about issues relating to the risk of bias in the studies but it is not designed to be scored. Rather the questions prompt the reviewer to assess study limitations. We did not synthesise outcomes in a meta-analysis due to heterogeneous outcomes, cancer types and time frames; rather a narrative synthesis was undertaken.

\subsection{RESULTS}

\subsection{Literature search}

Our initial database search revealed 384 citations of which 74 were duplicates. Reference screening of these papers revealed a further 33 potentially eligible studies. After screening 343 titles, 232 were excluded as shown in Figure 1. Abstract screening of 111 citations resulted in 31 full-text articles assessed for eligibility. After further excluding 6 records the final number of studies included in the review was 25 (Table 1). The main reasons for exclusion were due to irrelevant topic, FT not being the primary outcome, focus on non-patient costs, small sample size $(<200)$ and wrong study type. 


\subsection{Description of studies}

The included studies were conducted in a range of countries but predominantly from USA: USA (14)[10-23], Singapore (1)[24], Korea (1) [25], Ireland (2)[26, 27], Italy (1) [28], India (1)[7], Canada (2)[29, 30], Australia (1)[31] and ASEAN nations (2)[6, 32] (Table 1). The 25 studies covered 271,732 cancer survivors, with study samples ranging from 268 to 197,840 . Half the studies (14) included participants with any type of cancer $[23,28,10,24,12,6,15,16,32,7,20-22,25], 1$ for adult onset cancers [17], 4 had a mix of 2-3 cancers (including breast and prostate cancers)[11, 19, 26, 27], 2 breast cancer [14, 30], 2 prostate cancer [29, 31], and 2 blood cancers [13, 18]. Eighteen studies (72\%) were cross-sectional and the remainder were prospective or retrospective cohort studies. The timing of the participants since their cancer diagnosis varied significantly across the studies but can be divided into those who collected data relatively early after diagnosis (within 2 years), longer term (beyond 2 years) and studies with participants 'any time' since diagnosis.

\subsection{Quality of studies}

Table 2 presents the outcomes of the quality assessment. The main strengths of the studies were that all had clearly stated objectives, had reasonable sample sizes (mean of 3079 excluding the extremely high sample in Ramsey 2013), many had response rates over $50 \%$, had clear population inclusion criteria, clearly stated outcome and independent variables and mostly used multivariable analyses to address confounding. The main limitations were that few studies were population-based, most were cross-sectional and diverse outcome measures hampered across-study comparisons. With cross-sectional designs, causal inferences between FT and determinants were not possible. It is probable that financial hardship existed prior to the cancer or due to other comorbidities and the cancer experience might have not caused but exacerbated FT. Directionality and temporality issues are also present in these cross-sectional designs. Studies using administrative data sets did not consider sample size calculations and therefore could be considered exploratory analyses. Although some samples were selected from large population-based datasets where response rates were not applicable, others could not be determined $[31,6,15,16,7,19]$. Those conducting surveys or interviews mostly had participation rates over $50 \%$ (12 studies) and a few did not [28, 24, 22, 23]. The generalisability of the study samples is therefore questionable. The choice of 'financial burden' outcome was often clearly defined, but remained subjective, unvalidated or tested for reliability. Conversely, the monetary assessments of OOP costs included different cost components, covered different time periods and were still open to recall bias. In addition, the reference of OOP costs to income levels was not made in which to judge burden of health relative to other household expenditures. This is important because, paradoxically, high OOPs paid by patients are only possible with sufficient income and therefore higher OOPs are linked to variables of higher socioeconomic status. Findings from four studies did not present results adjusted for potential confounders [13, 31, $17,25]$ and therefore should be interpreted with caution.

\subsection{Summary of findings}

The measures of FT varied widely among the studies. They were categorised as:

1) monetary measures: currency values of OOPs and percentage of OOPs to income ratios; 
2) objective measures: question sets on tangible solutions to ease financial burden such as to increase debt levels, borrow money from family or friends, sell assets, withdraw money from retirement or savings funds, file for bankruptcy; and

3) subjective measures: question sets on perceptions of cancer-related financial burden and cover the psychological impact.

Within the monetary measures of OOPs, these included either direct medical expenses or direct and indirect expenses (i.e., travel, accommodation, parking).

The studies reported 47 measures of FT with most reporting more than one measure using the above categories; 22 (47\%) monetary measures, 9 (21\%) objective measures and 16 (34\%) subjective measures. In addition to quantifying FT, the impacts or consequences of FT were also outcomes for some studies (16 total measures). These included treatment non-adherence, changes made to insurances, choice of end-of-life care and health-related quality of life. Also, changes to work participation occurring concurrently with FT were further reported by $7(10 \%)$ studies in the context of FT. Figure 2 specifically outlines the dimensions of financial burden including all the above measures (70 total measures). Direct comparisons across studies was problematic due to different outcome measures, different time periods covered and the statistical approaches used ranging from descriptive statistics or simple ratios to multivariate modelling.

When a definition of FT in monetary terms was provided, these varied from 'catastrophic spending' defined as OOPs greater than $30 \%$ of household income [6,32], greater than $20 \%$ of household income [11] and the top quartile of OOPs [30]. Nevertheless, the studies indicated the frequency of FT among cancer survivors ranged from $28 \%$ to $48 \%[11,13,6,7,22,25]$. When FT involved answering objective or subjective questions, the frequency of FT ranged from $16 \%$ to $73 \%[10,24$, $16-19,26,23]$.

Most studies used statistical approaches to control for potential confounding in assessing FT as an outcome variable. Irrespective of the quantitative or subjective FT outcome used, in adjusted statistical models, the determinants of FT included: being female $[6,22]$, low income at baseline [6, 32 , 22], loss of income [30, 22], younger age [29, 17, 18, 20, 22], adjuvant therapies [11, 29, 17, 30], anti-neoplastic therapies $[11,15]$ more recent diagnosis [29, 31, 22], advanced cancer [32], no health insurance [6,32] and living further away from treatment centres [28, 30]. Several studies excluded stage of cancer in their analyses [17, 7, 22]. Also some ethnic groups in the USA (African American [19], Hispanics) consistently reported higher financial burden among cancer survivors, even after adjustment for income, education \& employment $[14,17,19,22,23]$. Similarly individuals with low income in developing countries with no universal health system or low levels of health insurance coverage, reported worse $\mathrm{FT}$, in addition to poor survival rates [6, 32]. These authors point to the competing outcome of mortality when assessing FT in developing countries which is not addressed in studies from developed countries. Baseline levels of FT [32] or financial stress [26] was also associated with FT following cancer treatment in two studies.

To examine FT specifically relating to cancer and no other competing comorbidities, three studies assessed the extent of financial burden in cancer sufferers versus non-cancer control groups [11, 7 , 20]. All indicated significantly higher burden for individuals with cancer relative to non-cancer control groups. Cumulative two-year spending on healthcare among a mixed cancer cohort in the US 
(1868 patients with cancer and 10,047 without cancer) was observed and $28 \%$ of patients with cancer reported a high OOP burden compared with $16 \%$ without cancer $(p<0.001)$ [11]. Using propensity matching, a study in India by Mahal et al (2013) found OOPs were significantly higher (Indian Rupee 5311 vs 1079) annually per person in households of cancer survivors and translating to $36-44 \%$ of annual household expenditure on cancer-related care [7]. Ramsey et al. (2013) reported that patients with cancer were 2.65 times more likely to go bankrupt than age-matched people without cancer [20].

Quality of life impacts were markedly worse for patients experiencing FT in three studies $[16,18,27]$ with mental well-being especially affected $[16,18,27]$. FT was reported to be the strongest predictor of quality of life in the US study by Fenn et al. (2014) [12]. Compared with individuals not reporting FT, impacts of FT included treatment non-adherence (frequency 27\%[10], 32\%[6], 35$70 \%[15])$ higher delays in care (17\% vs 7.4\%)[17], more patients forgoing care [17] and lost insurance (29\%)[13]. One study looking at choice of end-of-life care [23], found hospitalised intensive care was more common in those experiencing FT because this shifted costs to third party payers even though dying at home was preferred by patients. Reduced work participation and accompanying income loss was reported as being associated with FT in several studies [13, 30, 22] with a Canadian study reporting wage loss was the most important determinant of decline [30].

\subsection{DISCUSSION}

This review affirms FT to be a major issue affecting a large proportion of cancer survivors. Up to $48 \%$ of participants in the reviewed studies reported FT in monetary terms and this was even higher when measured in subjective terms. There were a range of possible questions or cost calculations that were used to constitute FT and this review has catalogued these as either monetary, objective (or tangible consequences) and subjective measures. The most commonly reported factors linked to FT were: being female, younger age, having a low income at baseline, receiving adjuvant therapies and having a recent diagnosis. High financial burden for cancer sufferers is in excess of that for persons not experiencing cancer (but possibly experiencing other chronic disease). The impact on patients can be debilitating to households, to quality of life and to optimal cancer care.

Our findings are similar to an earlier review of 10 studies, all cross-sectional but focussing on subjective measures of FT [33]. Although FT is a complex problem, greater awareness and acknowledgement of FT is likely to lead to solutions towards optimal patient outcomes by cancer care professionals, governments, patients and families and welfare providers, when necessary. FT is a household phenomenon and although this literature predominantly focusses on the financial outgoing expenses, it is also a function of the financial incomings, usually from employment, that are often reduced while undergoing cancer care. This is not apparent in the studies in this review but as the authors of one study stated, wage losses from the cancer treatment and recovery may be more important than OOPs incurred by households [30]. A critical underlying complication of the affordability of medical care is the potential for job loss, work absence and workplace discrimination, experienced during the course of prolonged cancer treatment. This is most apparent in developing countries where those on low incomes experienced higher mortality rates (from lack of health care) and higher catastrophic spending levels [6, 32]. 
Suggestions to ameliorate the financial burden for patients in tangible ways has included mandating the full disclosure by doctors of estimated fees and charges related to treatment from all sources, improved communication between health professionals and patients to raise any financial concerns and the ability patients to return to work should they need/wish to and creating opportunities for patients to make treatment decisions fully informed of the likely burden. Appropriate discussions about financial concerns should begin from the start of treatment and critical time points (e.g. completion of treatment), preparing patients and their families for the potential financial effects that could have an ongoing impact. Furthermore, screening tools may assist health professionals to identify those patients at high risk and refer them to support services.

A limitation of the review was the complexity of the topic and the absence of firm definitions or a conceptual model informing this body of evidence. Beyond the scope of this review, we omitted the rich data covered by qualitative studies on this topic. However, the categories used in reporting the collective outcomes of the included studies may help researchers design studies in future. It is encouraged that researchers use a standardized tool for assessing FT and there is one now available which was published in 2014 [34]. Briefly, the COST-FACIT was developed by Souza et al. (2014), and is an 11-item survey covering objective and subjective questions covering financial stress and workrelated issues during the past 7 days and using a Likert scale from 'Not at all' to 'Very much' [34]. In addition, as work income reductions are an important aspect of FT, the iMTA Productivity Cost Questionnaire (iPCQ) may also be useful in future research [35]. The iPCQ measures productivity losses of paid work due to absenteeism and presenteeism and unpaid work with 18 items and phrased over the past 4 weeks [35]. Both these instruments are generic and are not confined to cancer populations and both developers have called for further validation studies [35, 34]. It is advisable to use both these tools to cover the employment and OOP aspects and to minimise use of unvalidated tools.

In addition to being a direct patient concern, FT exposes serious system-level deficiencies around the way health systems are organised. Health system reforms in many settings are critical for minimizing FT and promoting equity in health care. Despite the developments for improving cancer control, the very high costs associated with cancer treatments is raising the issue of the capacity to afford these resources and whether budgets can sustain such spending. The Sustainable Development Solutions Network promotes universal health care and emphasizes that in order for nations to provide equality of access to necessary health care to their entire population, financing options which reduce out-of-pocket spending are fundamental [3]. Re-allocation of health resources can occur through, for example, investing in cost-effective preventive care, reducing use of services that offer little or no benefit, linking payments to the value of services received and increasing the use of information technology to populations in hard-to-reach locations [3]. Omitted from these options are increasing user fees and/or private health insurance coverage which serve only to exacerbate the difficulty for individuals meeting the financial demands of treatments. Health system structures and funding have a large influence on the experience of FT. At the extreme, this is emphasized in countries with poor or no public health system, where households pay entirely to receive treatment and clearly face catastrophic burdens, and high mortality [6]. However, the more granular differences among patients experiencing FT within complex health systems and shared funding models remain unknown. For patients with private health insurance, the review found mixed results as to whether FT was more or less protected. In Australia, men with prostate cancer experienced FT and higher out-of-pocket expenses when they were privately insured versus public hospital patients [31], which 
appears to be a product of the unregulated market in which specialists practice price discrimination [36]. However, the opposite was true in the US and other South East Asian countries, where patients without health insurance were more likely to report FT compared to those with health insurance $[13,6,37,4,22]$ but were not always protected from FT.

In countries such as Australia, New Zealand, Canada and the UK, government funding of new healthcare services and interventions involve organisations that perform health technology assessments that assess the value of new medicines and other services (http://www.inahta.org/). Their role is to weigh up the expected costs of their wide adoption in terms of patient outcomes and safety. Often the benefits of new cancer therapies for metastatic disease are small, and may not provide sufficient value at the prices private industry seeks for their provision. While these assessments appear lengthy, they are critical in the balanced and careful adoption of safe, effective and cost-effective treatments [38]. Developing countries in South-East Asia and Latin America are also adopting these systematic value assessments because they offer a thorough and ethical basis for decision-making involving public funds. From the patient's perspective, although new high-cost cancer medicines are often refused or delayed for public funding, leading to patient advocacy, crowd-funding and medical tourism to access them, they may not understand the lack of evidence base supporting these medicines. There is an important role for public engagement in health technology assessment so they are able to have their views incorporated into funding decisions [39].

Further research is warranted on FT and its impacts on treatment non-adherence in the longer term. There are several other reasons aside from affordability explaining non-adherence ranging from patient medication beliefs, patient age, extent of side-effects, multiple doses, and provider education and communication skills [40]. The studies in this review indicate short-term observations of non-adherence but there are likely to be potential health system costs that have not been thoroughly assessed. Non-adherence may be temporarily cost-saving for patients but it has wider downstream implications for health services [41]. For new high-cost oral anti-neoplastic agents within oncology, we are only beginning to understand that high levels of non-adherence occur despite the more convenient oral mode of delivery [40].

\subsection{CONCLUSIONS}

Minimising FT is critically important for patients and also important for health system structure and reforms. Patients and providers need to take control at seeking information on costs and exploring inexpensive options. More recognition of both the income and expenses side of financial hardship needs to occur among clinicians and researchers. Using standardized tools, prospective and longitudinal designs will improve our understanding of FT. 
Table 1: Summary of study findings

\begin{tabular}{|c|c|c|c|c|c|c|c|}
\hline $\begin{array}{l}\text { First author \& } \\
\text { Year }\end{array}$ & $\mathbf{N}$ & Country & Type of study & Cancer type & $\begin{array}{l}\text { Measured } \\
\text { outcomes }\end{array}$ & Time frame & Main findings \\
\hline Baili 2016 [28] & 296 & Italy & $\begin{array}{l}\text { Cross- } \\
\text { sectional } \\
\text { phone } \\
\text { interviews }\end{array}$ & Any cancer site & $\begin{array}{l}\text { Mean monthly } \\
\text { medical OOP cost } \\
\text { by region }\end{array}$ & $\begin{array}{l}\text { 5-10 years from } \\
\text { diagnosis, 2003- } \\
2007\end{array}$ & $\begin{array}{l}\text { On average, a patient in the north spent } € 69 \text { monthly, against } € 244 \text { in the south. } \\
\text { The main differences are for transport/ accommodation to cancer treatment } \\
\text { centre. }\end{array}$ \\
\hline $\begin{array}{l}\text { Bestvina } 2014 \\
{[10]}\end{array}$ & 300 & USA & $\begin{array}{l}\text { Cross- } \\
\text { sectional } \\
\text { in-person } \\
\text { interviews }\end{array}$ & Any cancer site & $\begin{array}{l}\text { Patient OOP cost, } \\
\text { financial distress } \\
\text { and odds of drug } \\
\text { non-adherence }\end{array}$ & $\begin{array}{l}\text { Baseline and } 3 \\
\text { months }\end{array}$ & $\begin{array}{l}16 \%(n=49) \text { reported high or overwhelming financial distress. } 19 \% \text { ( } n=56) \\
\text { reported talking to their oncologist about cost. } 27 \% \text { ( } n=77) \text { reported medication } \\
\text { nonadherence. Drug nonadherence was associated with cost discussion OR } \\
2.58 ; 95 \% \mathrm{Cl}, 1.14 \text { to } 5.85 \text {, financial distress OR=1.64,95\%Cl, } 1.38 \text { to } 1.96 \text { and } \\
\text { higher financial burden than expected OR=2.89; } 95 \% \mathrm{Cl}, 1.41 \text { to } 5.89 \text {. }\end{array}$ \\
\hline $\begin{array}{l}\text { Chan } 2013 \\
{[24]}\end{array}$ & 516 & Singapore & $\begin{array}{l}\text { Cross- } \\
\text { sectional } \\
\text { study, single- } \\
\text { centre, } \\
\text { prospective }\end{array}$ & Any cancer site & $\begin{array}{l}\text { Financial burden } \\
\text { for patients }>50 y r s \\
\text { Perceptions of } \\
\text { cancer treatment } \\
\text { costs }\end{array}$ & $\begin{array}{l}\text { Unclear, received } \\
\text { active anticancer } \\
\text { drug therapy within } \\
30 \text { days prior to } \\
\text { interview date }\end{array}$ & $\begin{array}{l}22.9 \% \text { of respondents stated they had difficulty paying for their cancer } \\
\text { treatment and that this financial burden affected their family. Only } 4.8 \% \text { of } \\
\text { respondents stated that they would reject a recommended treatment for } \\
\text { financial reasons. }\end{array}$ \\
\hline $\begin{array}{l}\text { Davidoff } 2013 \\
\text { [11] }\end{array}$ & 1,868 & USA & $\begin{array}{l}\text { Cohort study } \\
\text { Retrospective, } \\
\text { observational }\end{array}$ & $\begin{array}{l}\text { Breast, lung, } \\
\text { prostate, colon, } \\
\text { other }\end{array}$ & $\begin{array}{l}\text { OOP costs of } \\
\text { Medicare } \\
\text { beneficiaries } \\
\text { (cancer vs non- } \\
\text { cancer) }\end{array}$ & $\begin{array}{l}\text { Cumulative 2-year } \\
\text { spending }\end{array}$ & $\begin{array}{l}1868 \text { with and } 10,047 \text { without cancer. Mean OOP spending for cancer patients } \\
\text { was } \$ 4727 \text {. Cancer patients faced an adjusted } \$ 976(P<.01) \text { incremental OOP } \\
\text { spending. } 28 \% \text { of pts with cancer experienced a high OOP burden compared } \\
\text { with } 16 \% \text { without cancer }(P<.001) \text {. }\end{array}$ \\
\hline $\begin{array}{l}\text { De Oliveira } \\
2014 \\
{[29]}\end{array}$ & 585 & Canada & $\begin{array}{l}\text { Cross- } \\
\text { sectional } \\
\text { survey } \\
\text { population- } \\
\text { based }\end{array}$ & Prostate cancer & $\begin{array}{l}\text { Time costs and } \\
\text { OOPs and } \\
\text { predictors }\end{array}$ & $\begin{array}{l}\text { Long-term }(2-13 \\
\text { years) since } \\
\text { diagnosis }\end{array}$ & $\begin{array}{l}\text { Mean time costs were } \$ 838 / \text { year and mean OOP costs were } \$ 200 / \text { year. } \\
\text { Although generally low, total costs represented approximately } 10 \% \text { of income } \\
\text { for lower income patients. Radical prostatectomy, younger age, poor urinary } \\
\text { function, current androgen deprivation therapy, and recent diagnosis were } \\
\text { significantly associated with increased costs. }\end{array}$ \\
\hline $\begin{array}{l}\text { Fenn } 2014 \\
{[12]}\end{array}$ & 2,108 & USA & $\begin{array}{l}\text { Cross- } \\
\text { sectional } \\
\text { in-person } \\
\text { interviews }\end{array}$ & Any cancer site & $\begin{array}{l}\text { Impact of financial } \\
\text { burden of cancer } \\
\text { on quality of life }\end{array}$ & $\begin{array}{l}\text { Unclear, no time } \\
\text { limit (everyone who } \\
\text { ever had cancer was } \\
\text { eligible) }\end{array}$ & $\begin{array}{l}\text { Patients who reported "a lot" of financial problems rated poorer physical health } \\
(18.6 \% \vee 4.3 \%, \mathrm{P}<.001) \text {, mental health }(8.3 \% \vee 1.8 \%, \mathrm{P}<.001) \text {, and satisfaction } \\
\text { with social activities and relationships }(11.8 \% \vee 3.6 \%, \mathrm{P}<.001) \text { compared to } \\
\text { those with no financial hardship. Financial hardship is the strongest } \\
\text { independent predictor of quality of life. }\end{array}$ \\
\hline $\begin{array}{l}\text { Goodwin } 2013 \\
{[13]}\end{array}$ & 762 & USA & $\begin{array}{l}\text { Cross- } \\
\text { sectional }\end{array}$ & $\begin{array}{l}\text { Multiple } \\
\text { myeloma }\end{array}$ & $\begin{array}{l}\text { Financial burden, } \\
\text { employment, } \\
\text { OOP \% of income, } \\
\text { insurance, } \\
\text { disability }\end{array}$ & $\begin{array}{l}\text { Unclear, any time } \\
\text { since diagnosis }\end{array}$ & $\begin{array}{l}33 \% \text { additional not working, } 29 \% \text { lost insurance, } 13 \% \text { retired during treatment, } \\
\text { OOP } 36 \% \text { of income in first year and } 28 \% \text { in most recent } 12 \text { months. }\end{array}$ \\
\hline $\begin{array}{l}\text { Gordon } 2015 \\
\text { [31] }\end{array}$ & 289 & Australia & $\begin{array}{l}\text { Cross- } \\
\text { sectional }\end{array}$ & Prostate cancer & $\begin{array}{l}\text { Self-reported OOP } \\
\text { costs of prostate }\end{array}$ & $\begin{array}{l}\text { Any time since } \\
\text { diagnosis, recently }\end{array}$ & $\begin{array}{l}\text { Men recently diagnosed }(n=65) \text { reported spending a median AU\$8000 } \\
\text { (interquartile range AU\$14 000) for their cancer treatment while } 75 \% \text { of men }\end{array}$ \\
\hline
\end{tabular}




\begin{tabular}{|c|c|c|c|c|c|c|c|}
\hline $\begin{array}{l}\text { First author \& } \\
\text { Year }\end{array}$ & $\mathbf{N}$ & Country & Type of study & Cancer type & $\begin{array}{l}\text { Measured } \\
\text { outcomes }\end{array}$ & Time frame & Main findings \\
\hline & & & $\begin{array}{l}\text { survey } \\
\text { Online }\end{array}$ & & $\begin{array}{l}\text { cancer diagnosis \& } \\
\text { treatment, } \\
\text { changes in } \\
\text { employment }\end{array}$ & $\begin{array}{l}\text { diagnosed within } 16 \\
\text { months of the } \\
\text { survey }\end{array}$ & $\begin{array}{l}\text { spent up to AU\$17 } 000 \text { (2012). Large variability in costs. Respondents in paid } \\
\text { employment at diagnosis stated they retired 4-5 years earlier than planned. }\end{array}$ \\
\hline $\begin{array}{l}\text { Jagsi } 2014 \\
{[14]}\end{array}$ & 1,502 & USA & $\begin{array}{l}\text { Longitudinal } \\
\text { study, } \\
\text { prospective }\end{array}$ & Breast cancer & $\begin{array}{l}\text { Long-term self- } \\
\text { reported OOP } \\
\text { medical expenses, } \\
\text { financial decline, } \\
\text { privation }\end{array}$ & $\begin{array}{l}9 \text { months since } \\
\text { diagnosis \& } 4 \text { years } \\
\text { later }\end{array}$ & $\begin{array}{l}\text { Median out-of-pocket expenses were } \$ 2,000 ; 17 \% \text { reported spending }>\$ 5,000 ; \\
12 \% \text { reported having medical debt } 4 \text { years post diagnosis. Debt varied } \\
\text { significantly by race: } 9 \% \text { of whites, } 15 \% \text { of blacks, } 10-17 \% \text { of Latinas. Ethnic } \\
\text { minority patients different even after adjustment for income, education, and } \\
\text { employment. }\end{array}$ \\
\hline $\begin{array}{l}\text { Jan } 2015 \\
{[6]}\end{array}$ & 4584 & $\begin{array}{l}8 \text { ASEAN } \\
\text { nations }\end{array}$ & $\begin{array}{l}\text { Prospective } \\
\text { longitudinal }\end{array}$ & Any & $\begin{array}{l}\text { odds ratios of } \\
\text { financial } \\
\text { catastrophe (FC) } \\
\text { deaths, treatment } \\
\text { discontinuation }\end{array}$ & $\begin{array}{l}\text { Baseline and 3- } \\
\text { months }\end{array}$ & $\begin{array}{l}\text { Surgical patients only. } \mathrm{FC}=\mathrm{UMI} \text { countries } 3 \%, 38 \% \mathrm{LI}, 48 \% \mathrm{LMI} \text {. Discontinued tx } \\
=32 \% \mathrm{UMI}, 22 \% \mathrm{LMI}, 6 \% \mathrm{LI} \text {, deaths = } 3 \% \mathrm{UMI}, 9 \% \mathrm{LMI}, 17 \% \mathrm{LI} \text {. Factors for high } \\
\mathrm{FC}=\text { women, lower SES affected all outcomes, health insurance protective of } \\
\text { discontinuation }\end{array}$ \\
\hline $\begin{array}{l}\text { Kaisaeng } 2014 \\
\text { [15] }\end{array}$ & 3791 & USA & $\begin{array}{l}\text { Cross- } \\
\text { sectional }\end{array}$ & Any. & $\begin{array}{l}2008 . \\
\text { Mean OOP per } \\
\text { day, per year, } \\
\text { discontinuation }\end{array}$ & 12 month data & $\begin{array}{l}\text { Study focussed on } 5 \text { drugs imatinib, erlotinib, anastrozole, letrozole \& } \\
\text { thalidomide. Patients on most expensive drugs (imatinib, erlotinib, } \\
\text { thalidomide) had daily OOP of } \$ 30 \text {, others } \$ 3 \text {. Medication discontinuation for } 5 \\
\text { drugs ranged from } 35 \% \text { imatinib to } 70 \% \text { thalidomide. Higher OOP linked to more } \\
\text { discontinuation. }\end{array}$ \\
\hline $\begin{array}{l}\text { Kale } 2016 \\
{[16]}\end{array}$ & 1380 & USA & $\begin{array}{l}\text { Cross- } \\
\text { sectional }\end{array}$ & $\begin{array}{l}\text { Any and any } \\
\text { time since tx }\end{array}$ & $\begin{array}{l}\text { Financial burden } \\
\text { ( } \geq 1 \text { yes to } 4 \\
\text { questions of } \\
\text { financial } \\
\text { problems, HRQoL }\end{array}$ & $\begin{array}{l}65 \%>5 \text { years from } \\
\text { diagnosis } \\
14 \% 3-5 \text { years from } \\
\text { diagnosis }\end{array}$ & $\begin{array}{l}\text { SF12 - MCS and PCS, Kessler and PHQ229\% financial burden, financial burden } \\
\text { sign linear association with PCS and MCS. MCS stronger than PCS. Multi log reg } \\
\text { - odds } 1.95 \text { higher depressed mood, } 3.41 \text { higher with >=3xFB. Nationally } \\
\text { representative sample from MEPS }\end{array}$ \\
\hline $\begin{array}{l}\text { Kent } 2013 \\
{[17]}\end{array}$ & 1556 & USA & $\begin{array}{l}\text { Cross- } \\
\text { sectional }\end{array}$ & $\begin{array}{l}\text { Adult onset } \\
\text { cancers - } \\
\text { treatment }\end{array}$ & $\begin{array}{l}\text { Cancer-related } \\
\text { financial problems } \\
1 \mathrm{Q} \text {, forgoing or } \\
\text { delaying care } 3 \mathrm{Q} \text { s }\end{array}$ & $\begin{array}{l}>1 \text { year from } \\
\text { diagnosis }\end{array}$ & $\begin{array}{l}31.8 \% \text { reported cancer-related financial problems, higher if younger age }<65 \text {, } \\
\text { blacks/Hispanics, recurrence multiple ca, chemo or rad, higher delays } 18 \% \text { vs } \\
7.4 \% \text {, forgone care much higher if FB }\end{array}$ \\
\hline $\begin{array}{l}\text { Khera } 2014 \\
{[18]}\end{array}$ & 268 & USA & $\begin{array}{l}\text { Cross- } \\
\text { sectional }\end{array}$ & Blood cancers & $\begin{array}{l}\text { Subjective and } \\
\text { objective financial } \\
\text { burden, OOPs }\end{array}$ & $\begin{array}{l}\text { Unclear, median } \\
\text { follow-up time } 2.3 \\
\text { years ( } 6 \text { mths to } 6.9 \\
\text { years) }\end{array}$ & $\begin{array}{l}73 \% \text { experienced subjective burden, } 35 \% \text { experienced behaviours affecting } \\
\text { health (non-adherence to medicines or appts), } 37 \% \$ 2-5 \mathrm{~K}, 13 \%>\$ 5 \mathrm{~K} \text { past } 3 \\
\text { months of survivors }<1 \text { year after hemoatopoietic cell transplantation, } 26 \% \\
\text { income decreased by }>50 \%, 25 \% \text { withdrew funds from retirement account. } \\
\text { Younger age and poor mental/phys status linked to worse financial burden. }\end{array}$ \\
\hline $\begin{array}{l}\text { Kimman } 2015 \\
{[32]}\end{array}$ & 9513 & $\begin{array}{l}10 \text { ASEAN } \\
\text { nations }\end{array}$ & $\begin{array}{l}\text { Prospective } \\
\text { longitudinal }\end{array}$ & $\begin{array}{l}\text { Any. } 26 \% \text { brca, } \\
11 \% \text { mouth, } \\
10 \% \text { colorectal, } \\
11 \% \text { cervix } \\
\end{array}$ & $\begin{array}{l}\text { Odds ratios of } \\
\text { financial } \\
\text { catastrophe (FC) } \\
\text { and deaths }\end{array}$ & Baseline, 3, 12 mths. & $\begin{array}{l}29 \% \text { had died at } 12 \text { mnths. } 48 \% \text { experienced FC ( }>30 \% \text { of income on medical } \\
\text { OOPs). Determinants of FC and deaths were low income, advanced ca, no health } \\
\text { insurance. } 54 \% \text { experienced hardship prior to cancer diagnosis. FC OR } 5.86 \\
\text { (95\%Cl:4.76-7.23). }\end{array}$ \\
\hline
\end{tabular}




\begin{tabular}{|c|c|c|c|c|c|c|c|}
\hline $\begin{array}{l}\text { First author \& } \\
\text { Year }\end{array}$ & $\mathbf{N}$ & Country & Type of study & Cancer type & $\begin{array}{l}\text { Measured } \\
\text { outcomes }\end{array}$ & Time frame & Main findings \\
\hline [30] & & & longitudinal & & $\begin{array}{l}\text { determinants of } \\
\text { high OOPs (upper } \\
\text { quartile) }\end{array}$ & diagnosis & $\begin{array}{l}\text { 2003). Low income families } 4.3 \% \text { OOP/income vs } 1.3 \% \text { high income. Factors of } \\
\text { high OOP were higher education, working at diagnosis, living }>50 \mathrm{~km} \text { away, } 2 \text { or } \\
3 \text { types of adjuvant treatment. Wage loss most important determinant of } \\
\text { decline. }\end{array}$ \\
\hline $\begin{array}{l}\text { Mahal } 2013 \\
\text { [7] }\end{array}$ & 1645 & India & $\begin{array}{l}\text { Cross- } \\
\text { sectional }\end{array}$ & Any cancer & $\begin{array}{l}\text { Healthcare use, } \\
\text { OOP expenditure, } \\
\text { workforce } \\
\text { participation }\end{array}$ & One year (2004) & $\begin{array}{l}\text { Propensity matched data on socioeconomics - hospital admissions, length of } \\
\text { stay, outpatient use significantly higher in cancer households, OOP significantly } \\
\text { higher INR } 5311 \text { vs } 1079 \text { annual per person, slightly lower work participation } \\
3.2 \% \text {. OOP exp } 36 \text { to } 44 \% \text { of annual household expenditure on cancer-related } \\
\text { care. }\end{array}$ \\
\hline $\begin{array}{l}\text { Pisu } 2015 \\
{[19]}\end{array}$ & 3432 & USA & Prospective & $\begin{array}{l}40 \% \text { Lung and } \\
60 \% \text { colorectal } \\
\text { cancer }\end{array}$ & $\begin{array}{l}\text { Economic } \\
\text { hardship based } \\
\text { on } 3 \text { subjective } \\
\text { questions }\end{array}$ & $\begin{array}{l}4 \text { and } 12 \text { months } \\
\text { after diagnosis }\end{array}$ & $\begin{array}{l}\text { Prevalence of hardship in } 68 \% \text { African Americans, } 58 \% \text { Hispanics, } 50 \% \text { Whites. } \\
\text { Hardship non-significant after adjustment for baseline factors for African } \\
\text { Americans and Hispanics, African Americans significant hardship vs whites } \\
\text { (Adjusted OR 1.69: } \mathrm{Cl} 1.24-2.30 \text { ). }\end{array}$ \\
\hline $\begin{array}{l}\text { Ramsey } 2013 \\
{[20]}\end{array}$ & 197,840 & USA & $\begin{array}{l}\text { Cross- } \\
\text { sectional, } \\
\text { non-cancer } \\
\text { controls }\end{array}$ & Any cancer & $\begin{array}{l}\text { Incidence and } \\
\text { relative risk of } \\
\text { bankruptcy }\end{array}$ & $\begin{array}{l}\text { 1995-2009 in } \\
\text { Washington state }\end{array}$ & $\begin{array}{l}\text { Cancer patients were } 2.65 \text { times more likely to go bankrupt than people without } \\
\text { cancer. Younger patients } 2-5 \text { times more likely if }<65 \text { years. First year costs } \\
\text { important. }\end{array}$ \\
\hline $\begin{array}{l}\text { Sharp } 2013 \\
{[26]}\end{array}$ & 654 & Ireland & $\begin{array}{l}\text { Population- } \\
\text { based, cross- } \\
\text { sectional }\end{array}$ & $\begin{array}{l}\text { Breast, prostate } \\
\text { and lung cancer }\end{array}$ & $\begin{array}{l}\text { Cancer-related } \\
\text { financial } \\
\text { stress and } \\
\text { financial strain on } \\
\text { psychological well- } \\
\text { being }\end{array}$ & $\begin{array}{l}\text { Diagnosis up to } 24 \\
\text { months previously } \\
\text { in } 2008 \text { enrolment } \\
\text { year }\end{array}$ & $\begin{array}{l}\text { Of } 654 \text { respondents, } 49 \% \text { reported increased financial } \\
\text { stress and } 32 \% \text { increased financial strain due to cancer. } \\
\text { Depression risk with financial stress (odds ratio }(\mathrm{OR})=2.79,95 \% \mathrm{Cl} 1.87-4.17) \\
\text { and financial strain }(\mathrm{OR}=3.56,95 \% \mathrm{Cl} 2.23-5.67) \text {. For severe or worse } \\
\text { depression (increased stress: } \mathrm{OR}=4.36,95 \% \mathrm{Cl} 2.35-8.10 \text {; increased strain: } \mathrm{OR}= \\
8.21,95 \% \mathrm{Cl} 3.79-17.77) \text {. }\end{array}$ \\
\hline $\begin{array}{l}\text { Sharp } 2016 \\
{[27]}\end{array}$ & 740 & Ireland & $\begin{array}{l}\text { Cross- } \\
\text { sectional }\end{array}$ & $\begin{array}{l}\text { Breast and } \\
\text { prostate cancer }\end{array}$ & $\begin{array}{l}\text { Cancer-related } \\
\text { financial } \\
\text { stress and } \\
\text { financial strain, } \\
\text { predictors }\end{array}$ & $\begin{array}{l}\text { Diagnosis up to } 24 \\
\text { months previously } \\
\text { in } 2008 \text { enrolment } \\
\text { year }\end{array}$ & $\begin{array}{l}\text { Financial stress lower in not working RR } 0.71(95 \% \mathrm{Cl} 0.58-0.86) \text { or retired RR } \\
0.48(95 \% \mathrm{Cl}: 0.34-0.68) . \text { Higher financial stress if dependents, fin stress at } \\
\text { baseline, had a mortgage, higher direct OOPs, increased bills post diagnosis. }\end{array}$ \\
\hline $\begin{array}{l}\text { Stump } 2013 \\
{[21]}\end{array}$ & 400 & USA & $\begin{array}{l}\text { Cross } \\
\text { sectional, } \\
\text { mixed } \\
\text { methods }\end{array}$ & Any cancer & $\begin{array}{l}\text { Qs on concerns of } \\
\text { treatment costs } \\
\text { plus qualitative. }\end{array}$ & $\begin{array}{l}50 \% 5 \text { years out } \\
29 \% 5-10 \text { years out } \\
13 \%>10 \text { years out } \\
8 \% \text { missing }\end{array}$ & $\begin{array}{l}\text { High prevalence of concerns (e.g. concerns about paying for cancer treatment } \\
\text { OR } 2.83(1.92-4.2) \text { ), the nature of concerns about costs differed by patient } \\
\text { characteristics - young/older, low optimism, low numeracy, income, education. }\end{array}$ \\
\hline $\begin{array}{l}\text { Tucker-Seeley } \\
2015 \\
{[42]}\end{array}$ & 281 & USA & $\begin{array}{l}\text { Longitudinal, } \\
\text { repeated } \\
\text { measures }\end{array}$ & Any cancer & $\begin{array}{l}\text { Financial hardship } \\
\text { (1Q) and intensive } \\
\text { care at end-of-life }\end{array}$ & $\begin{array}{l}\text { Median } 4.4 \text { months } \\
\text { before death }\end{array}$ & $\begin{array}{l}29 \% \text { reported financial hardship based on using up savings, this was significantly } \\
\text { associated with more intensive care at end-of-life in hospital after adjustment } \\
\text { for confounders, intensive care may lower OOPs for families (is covered by } \\
\text { insurance or families) but dying at home is preferred. }\end{array}$ \\
\hline $\begin{array}{l}\text { Yabroff } 2016 \\
{[22]}\end{array}$ & 1202 & USA & $\begin{array}{l}\text { Cross- } \\
\text { sectional }\end{array}$ & $\begin{array}{l}\text { Any cancer, any } \\
\text { time since }\end{array}$ & $\begin{array}{l}\text { Material financial } \\
\text { hardship (4Qs) }\end{array}$ & $\begin{array}{l}22 \% 1-5 \text { years out } \\
42 \% \geq 5 \text { years out }\end{array}$ & $\begin{array}{l}\text { Younger age }<65 \text { years more material } 28.4 \% \text { vs } 13.8 \% \text { and psychological } 31.9 \% \\
\text { vs } 14.7 \% \text { hardship. Adjusted analyses - younger, female, non-white, changed }\end{array}$ \\
\hline
\end{tabular}




\begin{tabular}{|c|c|c|c|c|c|c|c|}
\hline $\begin{array}{l}\text { First author \& } \\
\text { Year }\end{array}$ & $\mathbf{N}$ & Country & Type of study & Cancer type & $\begin{array}{l}\text { Measured } \\
\text { outcomes }\end{array}$ & Time frame & Main findings \\
\hline & & & & & $\begin{array}{l}\text { and psychological } \\
\text { hardship (worry } \\
\text { over bills) }\end{array}$ & $10 \%$ missing & $\begin{array}{l}\text { employment had more material hardship. Uninsured, low income, recent } \\
\text { treatment had more psychological hardship. }\end{array}$ \\
\hline $\begin{array}{l}\text { You } 2013 \\
{[25]}\end{array}$ & $\begin{array}{l}17000 \\
\text { to } \\
35000\end{array}$ & Korea & $\begin{array}{l}\text { Time trend, } \\
\text { cross- } \\
\text { sectional from } \\
2003-2010\end{array}$ & $\begin{array}{l}\text { Any cancer, } \\
\text { hospitalization }\end{array}$ & $\begin{array}{l}\text { Absolute OOP, } \\
\text { OOP ratio = } \\
\text { OOP/total exp } \\
\text { from national } \\
\text { insurer }\end{array}$ & 2003 to 2010 & $\begin{array}{l}\text { OOP ratio } 30 \% \text { down from } 45 \% \text { in } 2003 \text {, policies to drop OOP but fees increased } \\
\text { and new technologies, thyroid cancer highest OOP }-3 \times \text { higher than breast }\end{array}$ \\
\hline
\end{tabular}

Acronyms: $\mathrm{CAN}=$ Canadian; INR= Indian rupee; FC = financial catastrophe; $\mathrm{LI}=$ low income; $\mathrm{LMI}$ = lower middle income; $\mathrm{MCS}$ = mental component score; OOP = out-of-pocket; OR = odds ratio; PCS = physical component score; $\mathrm{Q}=$ question; $\mathrm{RR}$ = relative risk; $\mathrm{UMI}=$ upper middle income 
Table 2: Quality assessment of studies

\begin{tabular}{|c|c|c|c|c|c|c|c|c|c|c|c|c|c|c|c|c|c|c|c|c|c|c|c|c|c|}
\hline Criteria & 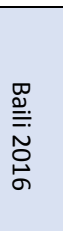 & 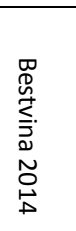 & 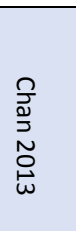 & 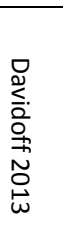 & 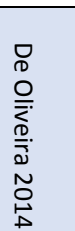 & 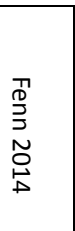 & 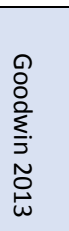 & 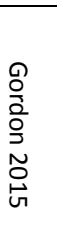 & 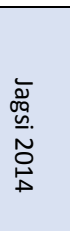 & 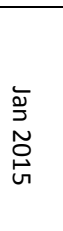 & 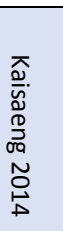 & $\begin{array}{l}\frac{\pi}{\omega} \\
\tilde{N} \\
\tilde{O} \\
\stackrel{\sigma}{\sigma}\end{array}$ & 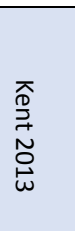 & 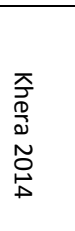 & 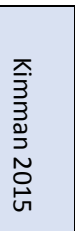 & 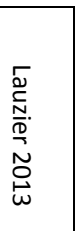 & 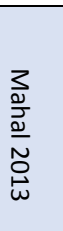 & $\begin{array}{l}\frac{0}{u} \\
\check{c} \\
\tilde{N} \\
\text { 它 }\end{array}$ & 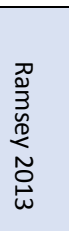 & $\begin{array}{l}\frac{n}{2} \\
\frac{a}{\partial} \\
\tilde{N} \\
\stackrel{\omega}{\omega}\end{array}$ & $\begin{array}{l}\frac{n}{0} \\
\frac{0}{0} \\
\tilde{O} \\
\stackrel{0}{\sigma}\end{array}$ & 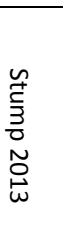 & 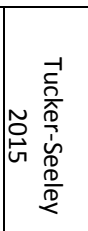 & 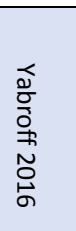 & $\begin{array}{l}\text { o } \\
\stackrel{1}{c} \\
\tilde{O} \\
\stackrel{\omega}{\omega}\end{array}$ \\
\hline 1. Clear research question? & $\mathrm{Y}$ & $\mathrm{Y}$ & $\mathrm{Y}$ & $\mathrm{Y}$ & $\mathrm{Y}$ & $\mathrm{y}$ & $y$ & $\mathrm{Y}$ & $\mathrm{Y}$ & $\mathrm{Y}$ & $Y$ & $\mathrm{Y}$ & $\mathrm{Y}$ & $\mathrm{Y}$ & $\mathrm{N}$ & $\mathrm{Y}$ & $Y$ & $\mathrm{Y}$ & Y & $\mathrm{Y}$ & $\mathrm{Y}$ & $\mathrm{Y}$ & $\mathrm{Y}$ & Y & $\mathrm{Y}$ \\
\hline $\begin{array}{l}\text { 2. study population clearly } \\
\text { specified? }\end{array}$ & Y & Y & Y & Y & Y & Y & Y & $\mathrm{Y}$ & Y & Y & Y & Y & Y & Y & Y & Y & Y & Y & Y & Y & Y & Y & Y & Y & $\mathrm{Y}$ \\
\hline 3. participation rate least $50 \%$ ? & $48 \%$ & $86 \%$ & $41 \%$ & NA & $53 \%$ & $61 \%$ & $76 \%$ & $\mathrm{CD}$ & $68 \%$ & $\mathrm{CD}$ & $\mathrm{CD}$ & $\mathrm{CD}$ & $61 \%$ & $56 \%$ & $55 \%$ & $83 \%$ & $\mathrm{CD}$ & $\mathrm{CD}$ & $54 \%$ & $54 \%$ & $68 \%$ & $\mathrm{CD}$ & $31 \%$ & $49 \%$ & NA \\
\hline $\begin{array}{l}\text { 4. recruited from the same or } \\
\text { similar populations? Were } \\
\text { inclusion and exclusion criteria } \\
\text { applied uniformly? }\end{array}$ & $Y$ & $Y$ & $Y$ & $Y$ & $\mathrm{Y}$ & $Y$ & $N$ & $\mathrm{~N}$ & $Y$ & $Y$ & $Y$ & $Y$ & $Y$ & $\mathrm{Y}$ & $Y$ & $\mathrm{Y}$ & $Y$ & $\mathrm{Y}$ & Y & $\mathrm{Y}$ & $\mathrm{Y}$ & $Y$ & Y & Y & $Y$ \\
\hline $\begin{array}{l}\text { 5. Was a sample size } \\
\text { justification? }\end{array}$ & $\mathrm{N}$ & $\mathrm{N}$ & $\mathrm{N}$ & NA & $N$ & $N$ & $Y$ & $Y$ & $\mathrm{~N}$ & NA & NA & NA & $N A$ & $\mathrm{~N}$ & $N$ & $\mathrm{~N}$ & NA & $\mathrm{N}$ & $N$ & $N$ & $\mathrm{~N}$ & $\mathrm{~N}$ & $N$ & $N$ & NA \\
\hline $\begin{array}{l}\text { 6. the exposure(s) prior to the } \\
\text { outcome(s) being measured? }\end{array}$ & $N$ & $\mathrm{~N}$ & $N$ & $\mathrm{~N}$ & $N$ & $N$ & $N$ & $\mathrm{~N}$ & $\mathrm{~N}$ & $\mathrm{~N}$ & $\mathrm{~N}$ & $\mathrm{~N}$ & $N$ & $\mathrm{~N}$ & $N$ & $N$ & $Y$ & $\mathrm{~N}$ & $N$ & $N$ & $\mathrm{~N}$ & $\mathrm{~N}$ & $Y$ & $N$ & $N$ \\
\hline $\begin{array}{l}\text { 7. Was the timeframe } \\
\text { sufficient? }\end{array}$ & $\mathrm{N}$ & $\mathrm{N}$ & $N$ & $\mathrm{~N}$ & $N$ & $N$ & $N$ & $\mathrm{~N}$ & $\mathrm{~N}$ & $Y$ & $\mathrm{~N}$ & $\mathrm{~N}$ & $N$ & $\mathrm{~N}$ & $Y$ & $\mathrm{Y}$ & $\mathrm{N}$ & $\mathrm{N}$ & $N$ & $N$ & $N$ & $\mathrm{~N}$ & Y & $N$ & $N$ \\
\hline $\begin{array}{l}\text { 8. examine different levels of } \\
\text { the exposure as related to the } \\
\text { outcome? }\end{array}$ & NA & $Y$ & $\mathrm{Y}$ & $Y$ & $\mathrm{Y}$ & $\mathrm{Y}$ & $\mathrm{Y}$ & $Y$ & $\mathrm{Y}$ & $Y$ & $Y$ & $\mathrm{Y}$ & $Y$ & $\mathrm{Y}$ & $Y$ & $\mathrm{Y}$ & $Y$ & $\mathrm{Y}$ & Y & Y & Y & $\mathrm{Y}$ & $N$ & $\mathrm{Y}$ & NA \\
\hline $\begin{array}{l}\text { 9. Were the exposure measures } \\
\text { valid, reliable? }\end{array}$ & $Y$ & $?$ & $\mathrm{Y}$ & $Y$ & $\mathrm{Y}$ & $Y$ & $\mathrm{Y}$ & $Y$ & $Y$ & $Y$ & $Y$ & $\mathrm{Y}$ & $Y$ & $\mathrm{Y}$ & $\mathrm{Y}$ & $\mathrm{Y}$ & $Y$ & $\mathrm{Y}$ & $Y$ & $\mathrm{Y}$ & Y & Y & Y & Y & NA \\
\hline $\begin{array}{l}\text { 10. Was the exposure(s) } \\
\text { assessed more than once over } \\
\text { time? }\end{array}$ & $N$ & $\mathrm{~N}$ & $N$ & $N$ & $N$ & $N$ & $\mathrm{~N}$ & $\mathrm{~N}$ & $\mathrm{~N}$ & $\mathrm{~N}$ & NA & $\mathrm{N}$ & $N$ & $\mathrm{~N}$ & $N$ & $\mathrm{~N}$ & NA & $\mathrm{N}$ & $\mathrm{N}$ & $N$ & $N$ & $\mathrm{~N}$ & $N$ & $N$ & $N$ \\
\hline $\begin{array}{l}\text { 11. Were the outcome } \\
\text { measures clearly defined, valid, } \\
\text { reliable? }\end{array}$ & $Y$ & $\mathrm{~N}$ & $N$ & $Y$ & $\mathrm{Y}$ & $N$ & $Y$ & $Y$ & $Y$ & $Y$ & $Y$ & $\mathrm{~N}$ & $N$ & $\mathrm{~N}$ & $\mathrm{Y}$ & $\mathrm{Y}$ & $Y$ & $\mathrm{~N}$ & Y & $N$ & $\mathrm{~N}$ & $\mathrm{~N}$ & $N$ & $N$ & $\mathrm{Y}$ \\
\hline $\begin{array}{l}\text { 12. outcome assessors blinded } \\
\text { to the exposure status of } \\
\text { participants? }\end{array}$ & $C D$ & $C D$ & $N$ & $C D$ & $C D$ & $\mathrm{~N}$ & $C D$ & $N$ & $\mathrm{~N}$ & $\mathrm{~N}$ & NA & $\mathrm{N}$ & $N$ & $\mathrm{~N}$ & $N$ & $\mathrm{~N}$ & $\mathrm{~N}$ & $\mathrm{~N}$ & $\mathrm{~N}$ & $N$ & $\mathrm{~N}$ & $\mathrm{~N}$ & $N$ & $N$ & $N$ \\
\hline $\begin{array}{l}\text { 13. Was loss to follow-up after } \\
\text { baseline } 20 \% \text { or less? }\end{array}$ & NA & $Y$ & NA & NA & NA & NA & NA & NA & $Y$ & NR & NA & NA & NA & NA & $\mathrm{Y}$ & $Y$ & NA & NR & NA & NA & NA & NA & $N$ & NA & NA \\
\hline $\begin{array}{l}\text { 14. potential confounding } \\
\text { variables measured and } \\
\text { adjusted statistically? }\end{array}$ & $Y$ & $\mathrm{Y}$ & $Y$ & $Y$ & $\mathrm{Y}$ & Y & $\mathrm{N}$ & $\mathrm{N}$ & Y & $Y$ & $Y$ & $\mathrm{Y}$ & $N$ & $Y$ & $\mathrm{Y}$ & $\mathrm{Y}$ & $Y$ & $\mathrm{Y}$ & $Y$ & $\mathrm{Y}$ & $Y$ & $Y$ & $\mathrm{Y}$ & $\mathrm{Y}$ & $N$ \\
\hline
\end{tabular}


Figure 1: PRISMA flow chart of study searches

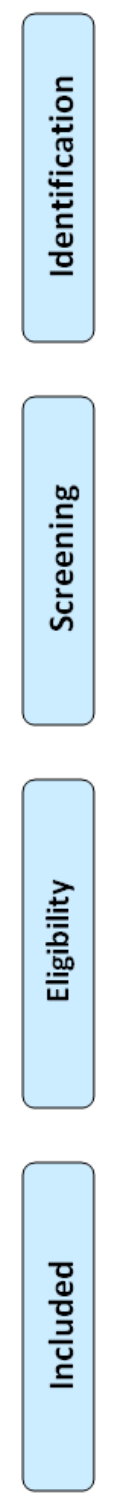

Records identified through database searching ( $n=384$ )
Additional records identified through reference checking ( $n=33)$

Records after 74 duplicates removed ( $n=343$ )

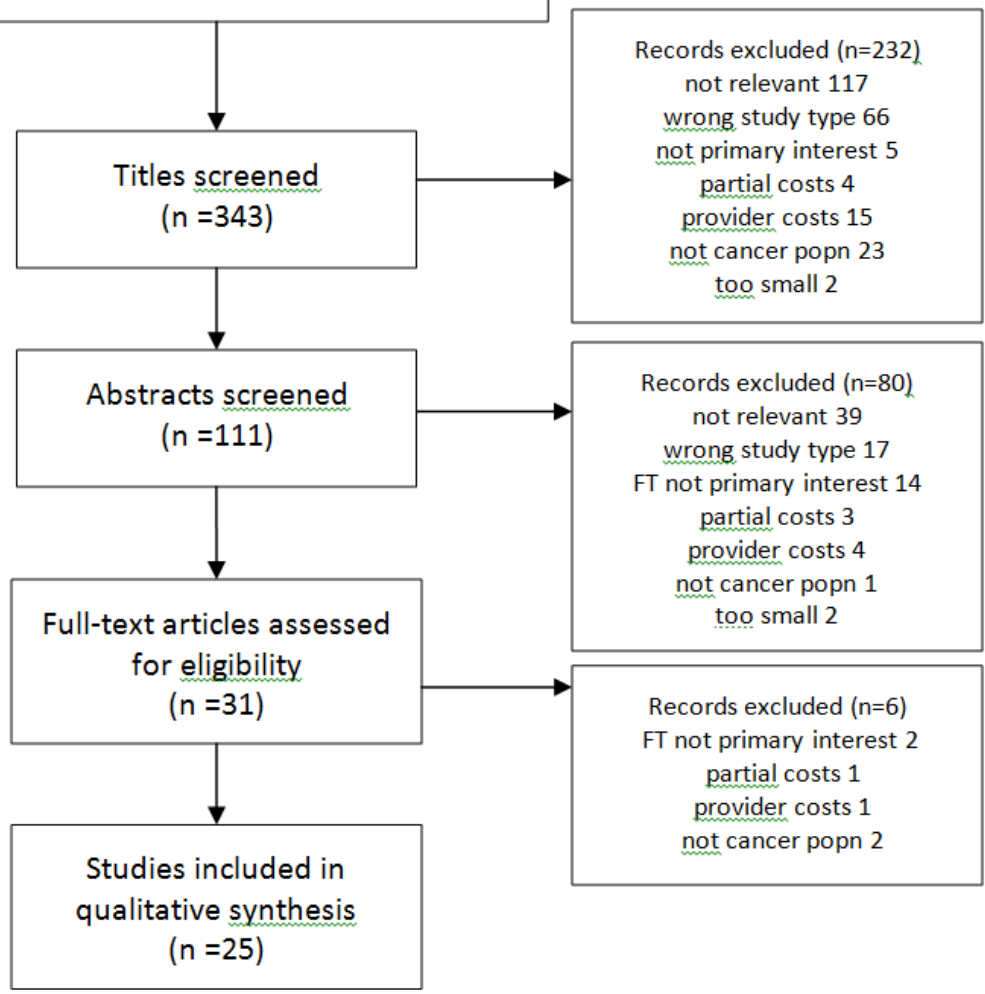


Figure 2: Frequency (\%) of financial burden component reported in the included studies

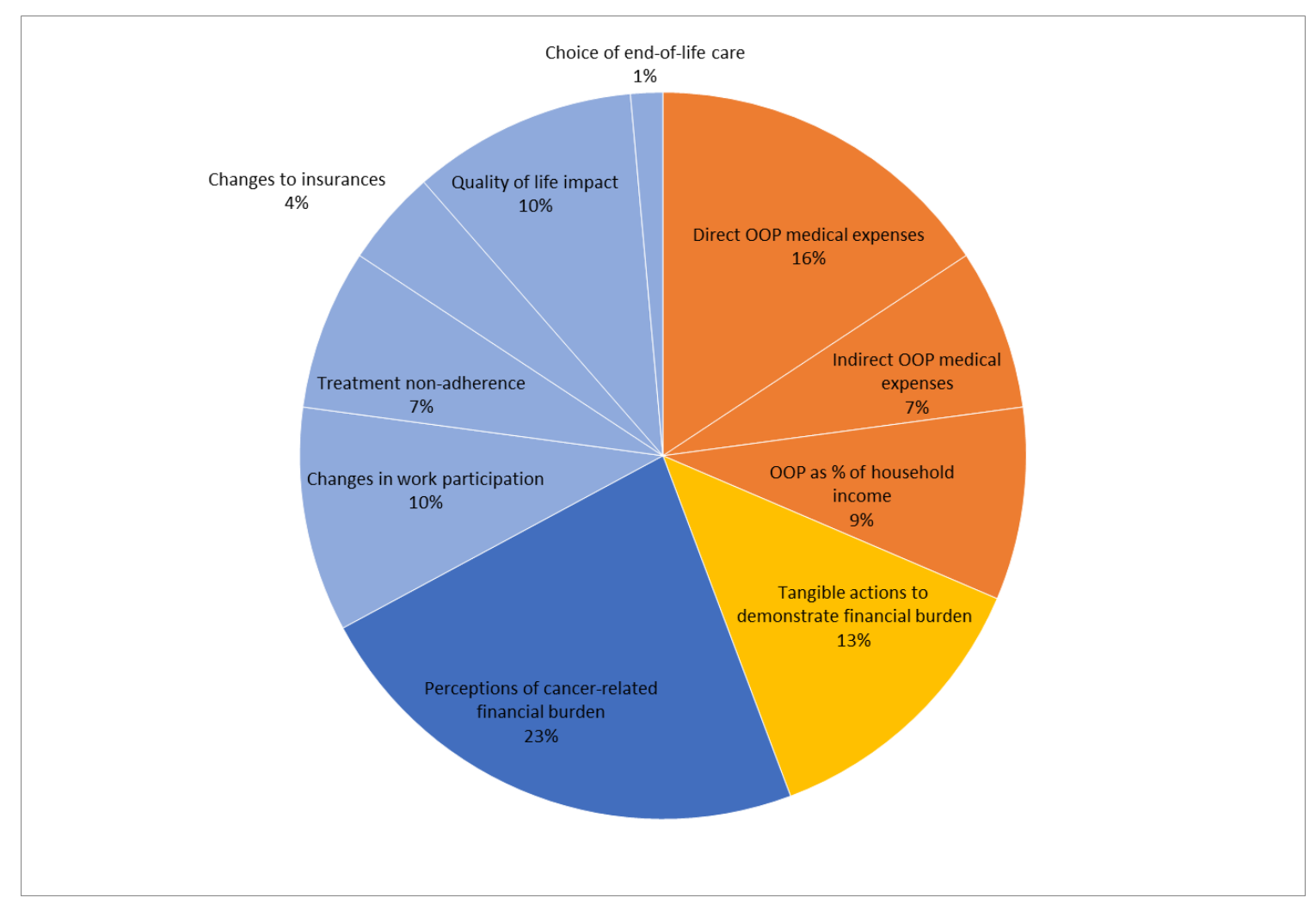

\section{Legend}

\begin{tabular}{|l|l|}
\hline & Monetary measures \\
\hline & Objective measures* \\
\hline & Subjective measures \\
\hline & Other impacts \\
\hline
\end{tabular}

*For example included borrowing money, increasing credit card debt, bankruptcy, forgone spending in other areas. OOP = out-of-pocket 


\section{References}

1. de Souza JA, Wong YN. Financial Distress in Cancer Patients. Journal of medicine and the person. 2013;11(2). doi:10.1007/s12682-013-0152-3.

2. Yabroff KR, Lawrence WF, Clauser S, Davis WW, Brown ML. Burden of illness in cancer survivors: findings from a population-based national sample. J Natl Cancer Inst. 2004;96(17):1322-30.

3. Laba TL, Essue BM, Jan S. Financing options to sustain Medicare: are we committed to universalism? Med J Aust. 2015;203(6):244-5.e1.

4. Tucker-Seeley RD, Yabroff KR. Minimizing the "financial toxicity" associated with cancer care: advancing the research agenda. Journal of the National Cancer Institute. 2016;108(5). doi:10.1093/jnci/djv410.

5. Zafar SY. Financial Toxicity of Cancer Care: It's Time to Intervene. Journal of the National Cancer Institute. 2016;108(5). doi:10.1093/jnci/djv370.

6. Jan S, Kimman M, Peters SA, Woodward M. Financial catastrophe, treatment discontinuation and death associated with surgically operable cancer in South-East Asia: Results from the ACTION Study. Surgery. 2015;157(6):971-82. doi:10.1016/j.surg.2015.02.012.

7. Mahal A, Karan A, Fan VY, Engelgau M. The economic burden of cancers on Indian households. PloS one. 2013;8(8):e71853. doi:10.1371/journal.pone.0071853.

8. Liberati A, Altman DG, Tetzlaff J, Mulrow C, Gotzsche PC, loannidis JP et al. The PRISMA statement for reporting systematic reviews and meta-analyses of studies that evaluate health care interventions: explanation and elaboration. J Clin Epidemiol. 2009;62(10):e1-34. doi: 10.1016/j.jclinepi.2009.06.006. Epub Jul 23.

9. National Institutes of Health. Quality Assessment Tool for Observational Cohort and CrossSectional Studies http://www.nhlbi.nih.gov/health-pro/guidelines/in-develop/cardiovascular-riskreduction/tools/cohort 2014.

10. Bestvina CM, Zullig LL, Rushing C, Chino F, Samsa GP, Altomare I et al. Patient-oncologist cost communication, financial distress, and medication adherence. Journal of oncology practice / American Society of Clinical Oncology. 2014;10(3):162-7. doi:10.1200/jop.2014.001406.

11. Davidoff AJ, Erten M, Shaffer T, Shoemaker JS, Zuckerman IH, Pandya N et al. Out-of-pocket health care expenditure burden for Medicare beneficiaries with cancer. Cancer. 2013;119(6):125765. doi:10.1002/cncr.27848.

12. Fenn KM, Evans SB, McCorkle R, DiGiovanna MP, Pusztai L, Sanft T et al. Impact of financial burden of cancer on survivors' quality of life. Journal of oncology practice / American Society of Clinical Oncology. 2014;10(5):332-8. doi:10.1200/jop.2013.001322.

13. Goodwin JA, Coleman EA, Sullivan E, Easley R, McNatt PK, Chowdhury N et al. Personal financial effects of multiple myeloma and its treatment. Cancer nursing. 2013;36(4):301-8.

doi:10.1097/NCC.0b013e3182693522.

14. Jagsi R, Pottow JA, Griffith KA, Bradley C, Hamilton AS, Graff J et al. Long-term financial burden of breast cancer: experiences of a diverse cohort of survivors identified through population-based registries. Journal of clinical oncology : official journal of the American Society of Clinical Oncology. 2014;32(12):1269-76. doi:10.1200/jco.2013.53.0956.

15. Kaisaeng N, Harpe SE, Carroll NV. Out-of-pocket costs and oral cancer medication discontinuation in the elderly. Journal of managed care \& specialty pharmacy. 2014;20(7):669-75. doi:10.18553/jmcp.2014.20.7.669.

16. Kale HP, Carroll NV. Self-reported financial burden of cancer care and its effect on physical and mental health-related quality of life among US cancer survivors. Cancer. 2016;122(8):283-9. doi:10.1002/cncr.29808.

17. Kent EE, Forsythe LP, Yabroff KR, Weaver KE, de Moor JS, Rodriguez JL et al. Are survivors who report cancer-related financial problems more likely to forgo or delay medical care? Cancer. 2013;119(20):3710-7. doi:10.1002/cncr.28262.

18. Khera N, Chang YH, Hashmi S, Slack J, Beebe T, Roy V et al. Financial burden in recipients of allogeneic hematopoietic cell transplantation. Biology of blood and marrow transplantation : journal 
of the American Society for Blood and Marrow Transplantation. 2014;20(9):1375-81.

doi:10.1016/j.bbmt.2014.05.011.

19. Pisu M, Kenzik KM, Oster RA, Drentea P, Ashing KT, Fouad M et al. Economic hardship of minority and non-minority cancer survivors 1 year after diagnosis: another long-term effect of cancer? Cancer. 2015;121(8):1257-64. doi:10.1002/cncr.29206.

20. Ramsey S, Blough D, Kirchhoff A, Kreizenbeck K, Fedorenko C, Snell K et al. Washington State cancer patients found to be at greater risk for bankruptcy than people without a cancer diagnosis. Health affairs (Project Hope). 2013;32(6):1143-52. doi:10.1377/hlthaff.2012.1263.

21. Stump TK, Eghan N, Egleston BL, Hamilton O, Pirollo M, Schwartz JS et al. Cost concerns of patients with cancer. Journal of oncology practice / American Society of Clinical Oncology. 2013;9(5):251-7. doi:10.1200/jop.2013.000929.

22. Yabroff KR, Dowling EC, Guy GP, Jr., Banegas MP, Davidoff A, Han X et al. Financial Hardship Associated With Cancer in the United States: Findings From a Population-Based Sample of Adult Cancer Survivors. Journal of clinical oncology : official journal of the American Society of Clinical Oncology. 2016;34(3):259-67. doi:10.1200/jco.2015.62.0468.

23. Tucker-Seeley RD, Abel GA, Uno H, Prigerson $\mathrm{H}$. Financial hardship and the intensity of medical care received near death. Psycho-oncology. 2015;24(5):572-8. doi:10.1002/pon.3624.

24. Chan A, Chiang YY, Low XH, Yap KY, Ng R. Affordability of cancer treatment for aging cancer patients in Singapore: an analysis of health, lifestyle, and financial burden. Supportive care in cancer : official journal of the Multinational Association of Supportive Care in Cancer. 2013;21(12):3509-17. doi:10.1007/s00520-013-1930-4.

25. You CH, Kang S, Kwon YD, Choi JH. Time trend of out-of-pocket expenditure among cancer inpatients: evidence from Korean tertiary hospitals. Asian Pacific journal of cancer prevention : APJCP. 2013;14(11):6985-9.

26. Sharp L, Carsin AE, Timmons A. Associations between cancer-related financial stress and strain and psychological well-being among individuals living with cancer. Psycho-oncology. 2013;22(4):74555. doi:10.1002/pon.3055.

27. Sharp L, Timmons A. Pre-diagnosis employment status and financial circumstances predict cancer-related financial stress and strain among breast and prostate cancer survivors. Supportive care in cancer : official journal of the Multinational Association of Supportive Care in Cancer. 2016;24(2):699-709. doi:10.1007/s00520-015-2832-4.

28. Baili P, Di Salvo F, de Lorenzo F, Maietta F, Pinto C, Rizzotto V et al. Out-of-pocket costs for cancer survivors between 5 and 10 years from diagnosis: an Italian population-based study. Supportive care in cancer : official journal of the Multinational Association of Supportive Care in Cancer. 2016;24(5):2225-33. doi:10.1007/s00520-015-3019-8.

29. de Oliveira C, Bremner KE, Ni A, Alibhai SM, Laporte A, Krahn MD. Patient time and out-of-pocket costs for long-term prostate cancer survivors in Ontario, Canada. Journal of cancer survivorship : research and practice. 2014;8(1):9-20. doi:10.1007/s11764-013-0305-7.

30. Lauzier S, Levesque P, Mondor M, Drolet M, Coyle D, Brisson J et al. Out-of-pocket costs in the year after early breast cancer among Canadian women and spouses. Journal of the National Cancer Institute. 2013;105(4):280-92. doi:10.1093/jnci/djs512.

31. Gordon LG, Walker SM, Mervin MC, Lowe A, Smith DP, Gardiner RA et al. Financial toxicity: a potential side effect of prostate cancer treatment among Australian men. European journal of cancer care. 2015. doi:10.1111/ecc.12392.

32. Kimman M, Jan S, Yip CH, Thabrany H, Peters SA, Bhoo-Pathy N et al. Catastrophic health expenditure and 12-month mortality associated with cancer in Southeast Asia: results from a longitudinal study in eight countries. BMC medicine. 2015;13:190. doi:10.1186/s12916-015-0433-1. 33. Azzani M, Roslani AC, Su TT. The perceived cancer-related financial hardship among patients and their families: a systematic review. Supportive care in cancer : official journal of the Multinational Association of Supportive Care in Cancer. 2015;23(3):889-98. doi:10.1007/s00520-014-2474-y. 
34. de Souza JA, Yap BJ, Hlubocky FJ, Wroblewski K, Ratain MJ, Cella D et al. The development of a financial toxicity patient-reported outcome in cancer: The COST measure. Cancer.

2014;120(20):3245-53. doi: 10.1002/cncr.28814. Epub 2014 Jun 20.

35. Bouwmans C, Krol M, Severens H, Koopmanschap M, Brouwer W, Hakkaart-van Roijen L. The iMTA Productivity Cost Questionnaire: A Standardized Instrument for Measuring and Valuing HealthRelated Productivity Losses. Value Health. 2015;18(6):753-8. doi: 10.1016/j.jval.2015.05.009. Epub Aug 20.

36. Johar M, Mu C, Van Gool K, Wong CY. Bleeding Hearts, Profiteers, or Both: Specialist Physician Fees in an Unregulated Market. Health Econ. 2016;23(10).

37. O'Connor JM, Kircher SM, de Souza JA. Financial toxicity in cancer care. The Journal of community and supportive oncology. 2016;14(3):101-6. doi:10.12788/jcso.0239.

38. Scott AM. Health technology assessment in Australia: a role for clinical registries? Aust Health Rev. 2016;31(10).

39. Wortley S, Tong A, Howard K. Community views and perspectives on public engagement in health technology assessment decision making. Aust Health Rev. 2016;7(10).

40. Greer JA, Amoyal N, Nisotel L, Fishbein JN, MacDonald J, Stagl J et al. A Systematic Review of Adherence to Oral Antineoplastic Therapies. Oncologist. 2016;21(3):354-76. doi:

10.1634/theoncologist.2015-0405. Epub 2016 Feb 26.

41. Osterberg L, Blaschke T. Adherence to medication. N Engl J Med. 2005;353(5):487-97.

42. Tucker-Seeley RD, Abel GA, Uno H, Prigerson $\mathrm{H}$. Financial hardship and the intensity of medical care received near death. Psycho-oncology. 2015;24(5):572-8. doi:10.1002/pon.3624. 